\title{
SELECTION OF THE PIQUA OMR
}

FUEL ELEMENT

By

E. B. BAUMEISTER

J. D. WILDE

This document is PUBLICLYRELABADL

A Kaver Authorizing Official

Dew $10 / 1 / 05$

\section{ATOMICS INTERNATIONAL}
A DIVISION OF NORTH AMERICAN AVIATION, INC.
P.O. BOX 309
CANOGA PARK, CALIFORNIA

CONTRACT MAAT LUTS50GEN-8 


\section{DISCLAIMER}

This report was prepared as an account of work sponsored by an agency of the United States Government. Neither the United States Government nor any agency Thereof, nor any of their employees, makes any warranty, express or implied, or assumes any legal liability or responsibility for the accuracy, completeness, or usefulness of any information, apparatus, product, or process disclosed, or represents that its use would not infringe privately owned rights. Reference herein to any specific commercial product, process, or service by trade name, trademark, manufacturer, or otherwise does not necessarily constitute or imply its endorsement, recommendation, or favoring by the United States Government or any agency thereof. The views and opinions of authors expressed herein do not necessarily state or reflect those of the United States Government or any agency thereof. 


\section{DISCLAIMER}

Portions of this document may be illegible in electronic image products. Images are produced from the best available original document. 


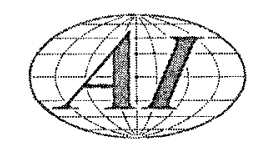

\section{DISTRIBUTION}

This report has been distributed according to the category "Physics and Mathematics" as given in "Standard Distribution Lists for Unclassified Scientific and Technical Reports" TID-4500 (15th Ed.), August 1, 1959. A total of 655 copies were printed.

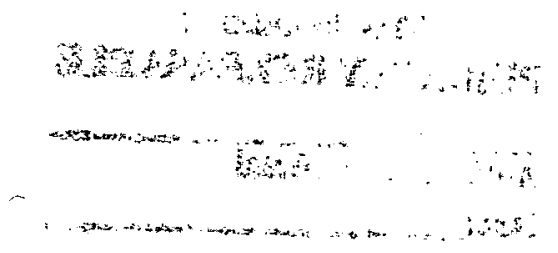




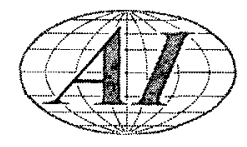

\section{CONTENTS}

Page

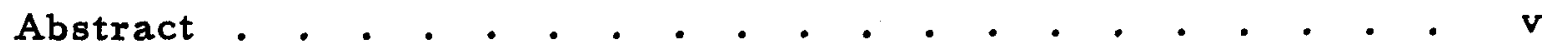

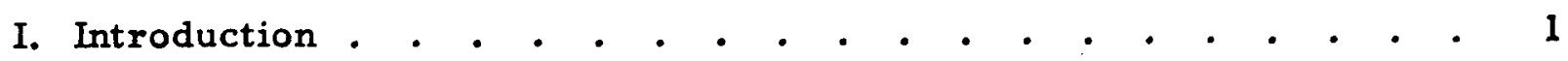

II. Description of the Fuel Elements . - . . . . . . . . . . 1

A. Square (Finned-Plate) Element . . . • • . . . . . . 1

B. Circular Element . • • • . • • • • • • • • • • . 1

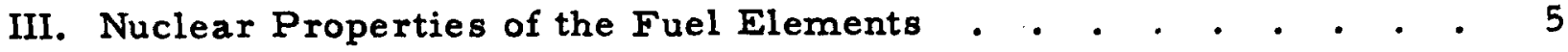

IV. Relative Performance of the Fuel Elements • . . . . . - . 7

V. Selection of the Fuel Element for the Piqua Reactor . . . . . 10

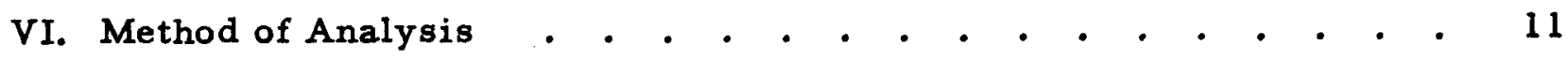

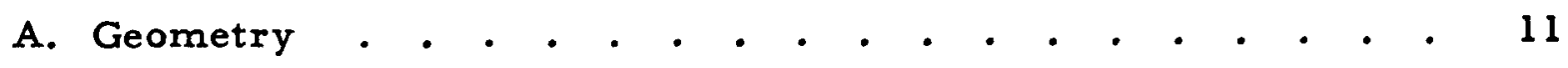

B. Power Capacity in the Hottest Fuel Element . . . . . . . 12

C. Heat Transfer Coefficient . . . . . . • . . . . • . 13

D. Effective Heat Transfer Area - . • • • • . . • . • . 13

E. Core Pressure Drop - • • • • • • • • • • • . • . 13

F. Burnout Heat Flux. • • • • • • • • • • • • . • . 15

G. Total Reactor Power . . . • • • . • • . . . . . . 15

H. Total Coolant Flow Rate . . • . . . . . . . . . . 15

VII. Results • • • • • • • . • • • • • • • • • • • . 18

A. Core Flux Peak-to-Average . . . . . . . . . . . . 18

B. Hot Channel Factors . . . . . . . . . . . . . . . 20

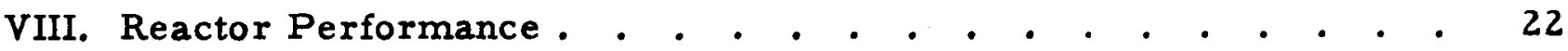

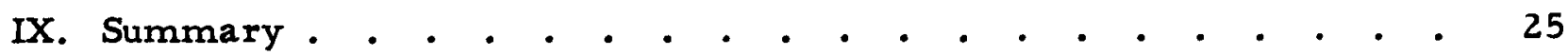

References • • • • • • • • • • • • • • • • • • • 27

Nomenclature • • . . . . . . . . . . . . . . . 29 


\section{TABLES}

Page

I. Relative Performance of Three Types of Fuel Elements . . . . 7

II. Relative Merits of the Fuel Element Types. . . . . . . . . 9

III. Properties of the Circular Fuel Element . . • . . . . . . 17

IV. Physical Properties of the Organic Coolant . . . . . . . . 17

V. Flux Peaking Factors in the Reactor Core . . . . . . . . . 18

VI. Manufacturing Tolerances for the Circular Element . . . . . 20

VII. Hot Channel Factors . . . . . . . . . . . . . . . . 21

VIII. Piqua Operating Conditions with the Circular Element . . . . . 23

\section{FIGURES}

1. Square (Parallel Flat Plate) Fuel Element Configuration . . . . 2

2. Circular (Concentric Cylindrical Shell) Fuel Element Configuration 3

3. Cell Configurations . . . . . . . . . . . . . . . . 4

4. Thermal Flux Distribution in the Circular Fuel Cell . . . . . 6

5. Heat Transfer Coefficient Correlation . . . . . . . . . . 14

6. Burnout Correlation . . . . . . . . . . . . . 16

7. Core Configuration. . . . . . . . . . . . . . . . . 19 


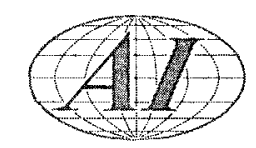

\begin{abstract}
Two types of aluminum-clad uranium alloy fuel elements, a square (parallel flat plate) and a circular (concentric cylindrical shell) are investigated to determine their relative suitability for use in the Piqua organic moderated reactor. Nuclear, thermal, and mechanical data are given, and considerations leading to selection of the circular element are presented. Design dimensions are listed and reactor thermal design and operating conditions are given for the proposed element.
\end{abstract}




\section{INTRODUCTION}

An earlier preliminary study ${ }^{1}$ compared the thermal performance of various types of fuel elements having a container box of square cross-section. These included elements containing pins normal to the direction of flow, plates in a baffled arrangement, and both finned and unfinned parallel plates. This reference study indicated that the most satisfactory thermal performance could be obtained from a finned-plate type element. However, after this investigation was completed, a cylindrical type of element was conceived which appeared to have excellent nuclear and thermal properties. Since total core fabrication costs of this element were estimated to be no greater than those of the flat-plate element, the present study was carried out to determine which of these two element types was capable of the better thermal and nuclear performance.

\section{DESCRIPTION OF THE FUEL ELEMENTS}

\section{A. SQUARE (FINNED-PLATE) ELEMENT}

The square element consists of finned plates equally spaced in a square container box, as shown in Figure 1. These elements are placed on a square lattice which may either be spaced or approach a close-packed arrangement. The two characteristic lattice configurations are shown in Figure 3. For the close-packed arrangement, all the moderator is located within the fuel element and acts as coolant. In the spaced lattice design, only a part of the moderator acts as the coolant, the remainder being located in the spaces between the elements.

\section{B. CIRCULAR ELEMENT}

The circular element is shown in Figure 2. These elements consist of two finned-concentric cylinders housed between cylindrical containers and spaced in a triangular lattice, as shown in Figure 3. It can be seen that only a small fraction of the total moderator acts as coolant and that most of the moderator is located between the elements and inside the inner container can. 


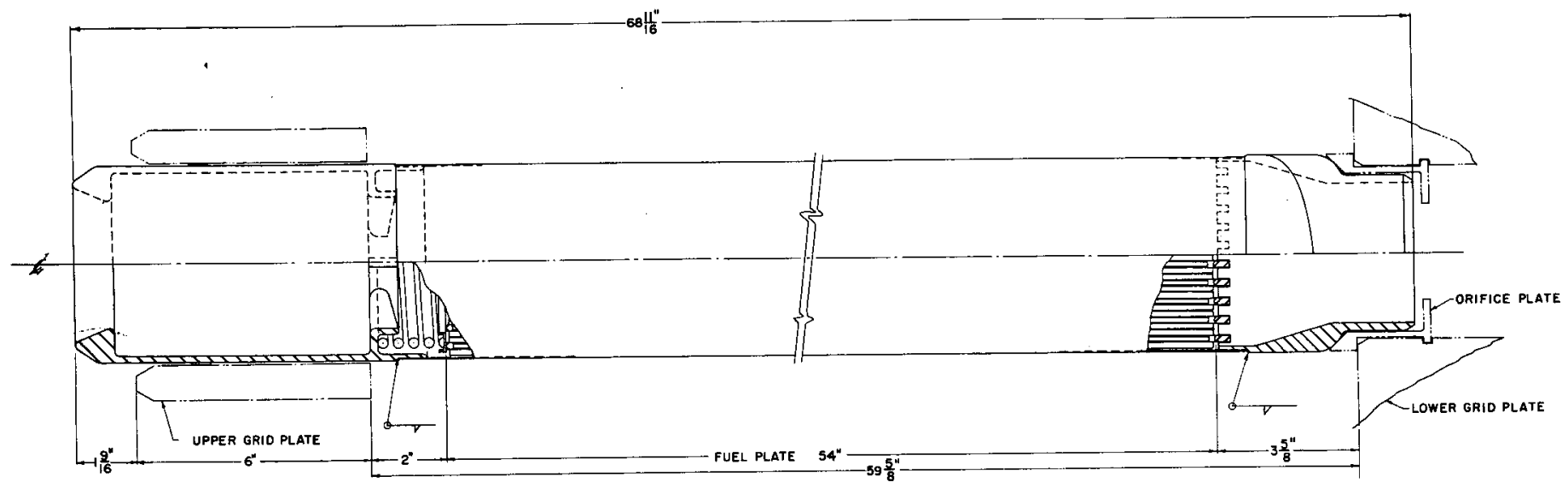

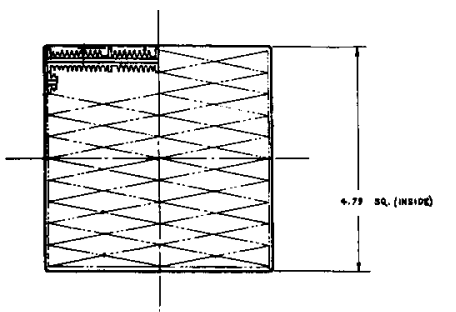

FUEL ELEMENT SECTION

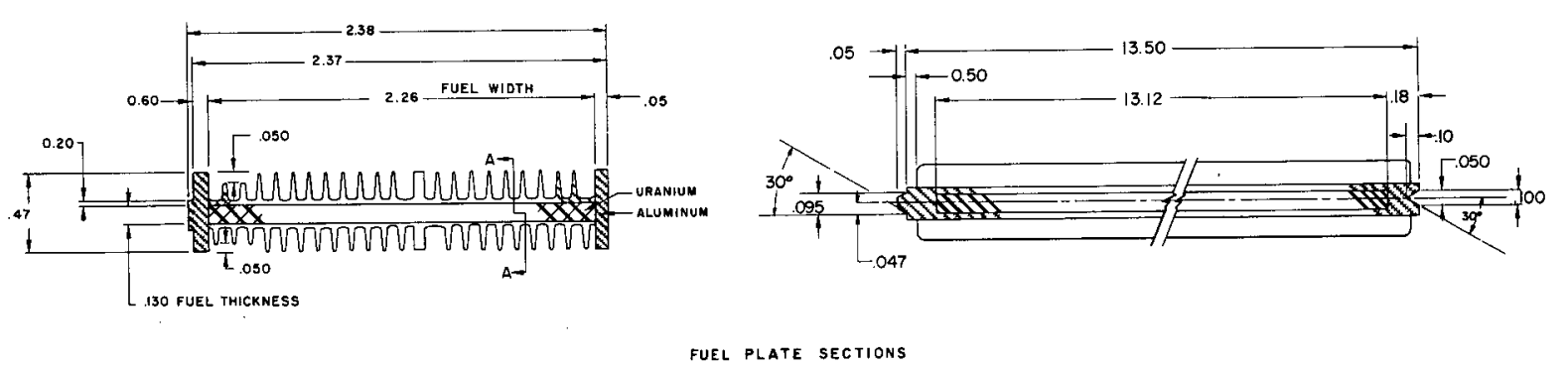

FUEL PLATE SECTIONS

Figure 1. Square (Parallel Flat Plate) Fuel Element Configuration 

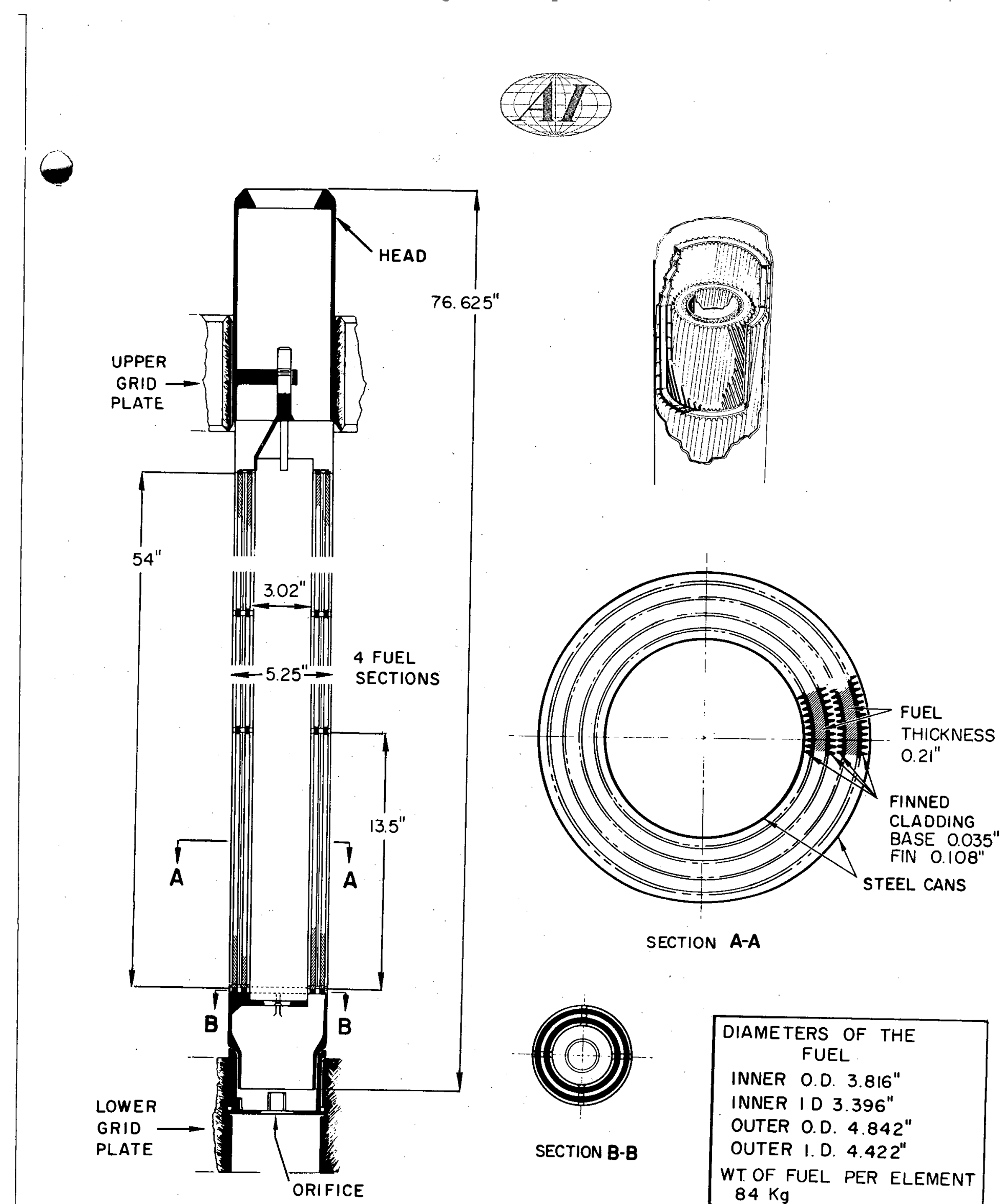

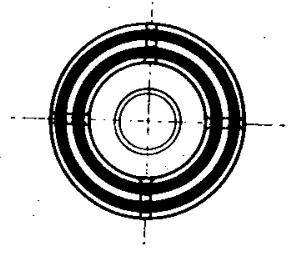

SECTION B-B
DIAMETERS OF THE FUEL

INNER O.D. 3.816" INNER I.D 3.396" OUTER O.D. $4.842^{\prime \prime}$ OUTER I.D. $4.422^{\prime \prime}$ WT OF FUEL PER ELEMENT $84 \mathrm{Kg}$

Figure 2. Circular (Concentric Cylindrical Shell) Fuel Element Configuration 


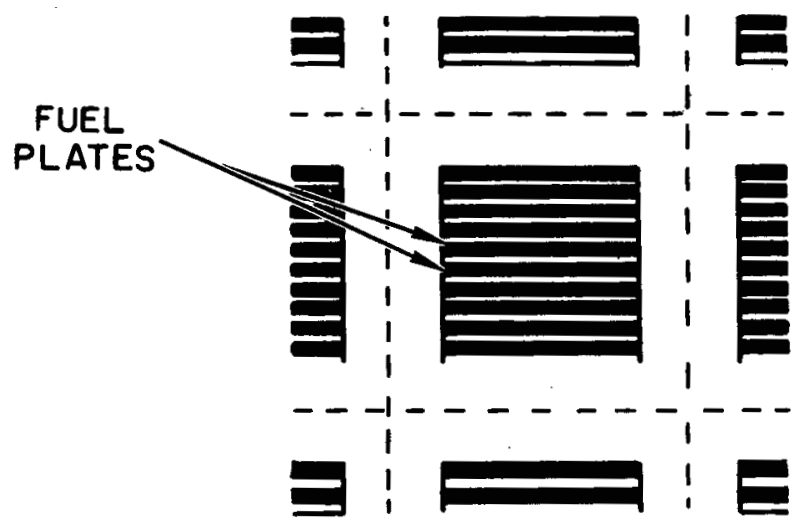

FINNED-PLATE ELEMENT SPACED LATTICE

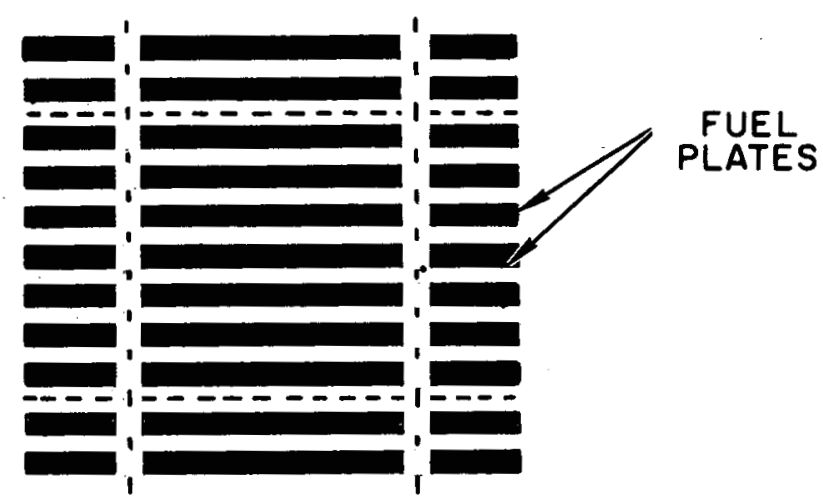

FINNED-PLATE ELEMENT CLOSE - PACKEDLATTICE

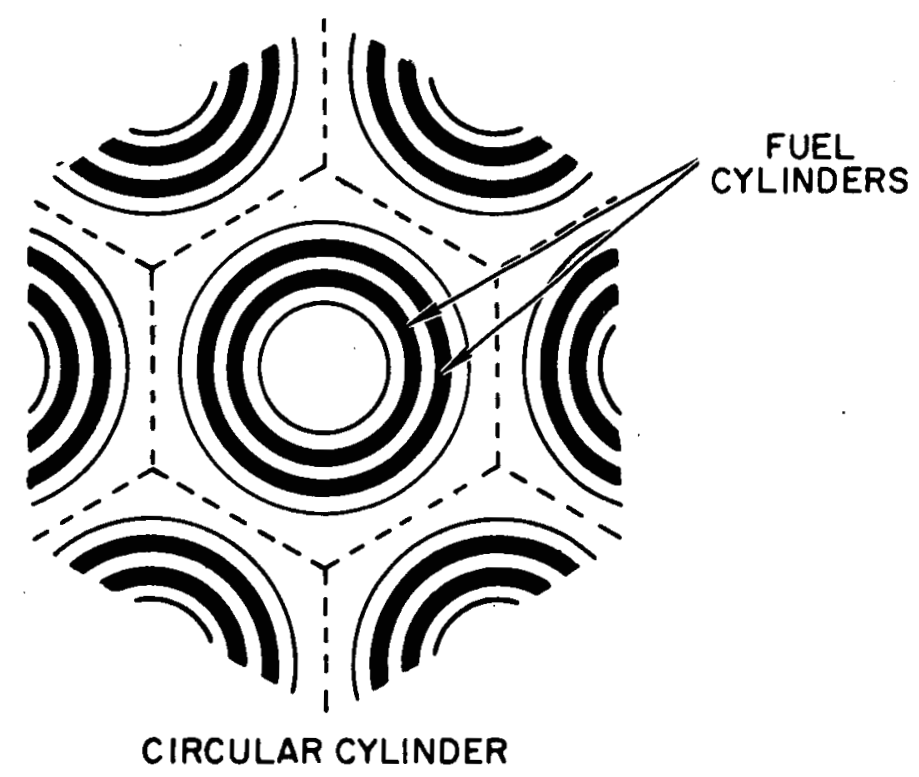

Figure 3. Cell Configurations 


\section{NUCLEAR PROPERTIES OF THE FUEL ELEMENTS}

Heterogeneous reactors permit the slowing down of neutrons to take place in a moderator region away from the fuel, thus reducing the resonance capture in the $\mathrm{U}^{238}$. Therefore, since the close-packed lattice is more nearly homogeneous than the spaced lattice, it possesses a lower resonance escape probability. However, the thermal utilization is greater for a close-packed lattice because the neutron flux is more nearly uniform. For reactors with low enrichment, the decrease in resonance escape probability usually overshadows the increased thermal utilization, thus requiring a close-packed lattice to have a higher enrichment than the spaced lattice for the same reactivity.

Because of the large moderator region exterior to the element, the spaced-lattice square element produces high flux peaking in the fuel, particularly in the corners of the element. The circular element eliminates local flux peaking in the fuel by providing moderator regions both inside and outside the element, giving a balanced neutron flux distribution that peaks only outside the fuel (see Figure 4). A small amount of flux peaking will occur around the circumference of the cylinders at the six corners of the cell boundary. 


\section{(A1)}

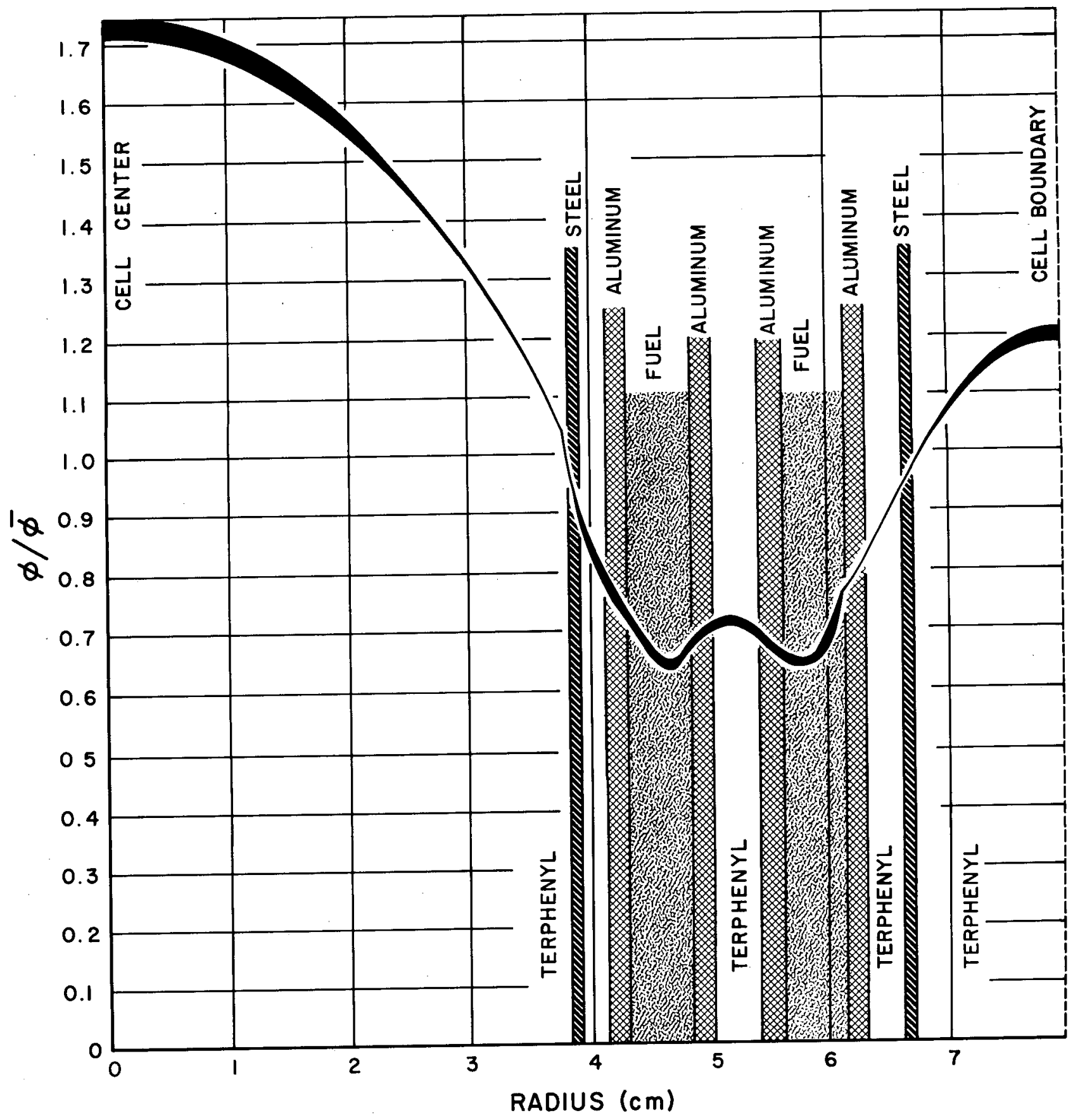

Figure 4. Thermal Flux Distribution in the Circular Fuel Cell 


\section{RELATIVE PERFORMANCE OF THE FUEL ELEMENTS}

Comparative calculations were carried out for the three fuel element arrangements. In each case, the calculations were for reactors of equal thermal power. Fuel element sizes of from 3.5 to 6 inches in a 6 -inch cell were considered for the square element, and triangular center-to-center spacings of from 6 to 8 inches were investigated for the circular element. Table I lists the results of these calculations for a 4.75-inch square element in a 6-inch square lattice, a 5.75-inch square element in a 6-inch close-packed lattice, and a 5.25 inch diameter circular element in a 6-inch triangular lattice. Arrangements with these dimensions were found to possess the best heat-transfer and nuclear properties of all the sizes considered for each type.

\section{TABLE I}

RELATIVE PERFORMANCE OF THREE T YPES OF FUEL ELEMENTS

\begin{tabular}{l|c|c|c}
\hline \multirow{2}{*}{ Fuel Element Type } & \multicolumn{2}{|c|}{ Square } & \multirow{2}{*}{ Circular } \\
\cline { 2 - 3 } & Spaced & Close Packed & \\
\hline \multirow{2}{*}{ Total flow rate } & 1.37 & 1.79 & 1.0 \\
Core pressure drop & 1.08 & 0.73 & 1.0 \\
Core pumping power & 1.48 & 1.31 & 1.0 \\
Reactor diameter \& length & 0.99 & 0.79 & 1.0 \\
Fuel cycle costs & 1.41 & 1.42 & 1.0 \\
Enrichment, \% & 2.0 & 3.4 & 2.0 \\
Element flux peaking & 1.63 & 1.30 & 1.05 \\
\hline
\end{tabular}

In discussing the performance of these elements; it is well to consider the following points:

1) Use of an Upper Grid Plate

In order to reduce the fuel costs of power reactors, it becomes necessary to redistribute fuel elements within the reactor at various stages of burnup. Using upper and lower grid plates, the fuel elements are held in place 


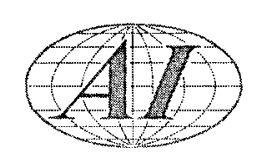

very easily. In the Piqua reactor, the close-packed square element does not readily accomodate an upper grid plate. This disadvantage might be overcome by a more complex mechanical arrangement in the core.

\section{2) Flux Peaking in the Element}

Flux peaking within the fuel element results in a variation of the heattransfer rate in each channel, thus permitting only a small portion of the element to operate at the limiting temperature. In the spaced square element, not only is the flux peaking more severe but there is also a non-uniform distribution of velocity across the coolant channel. Velocities (and hence heat transfer coefficients) are least in the "corners" of the channel coincident with the presence of the peak fluxes. There are no "corners" in the circular element and the flux peaking is considerably reduced for reasons mentioned earlier. In addition, the spiralled fins transport the coolant around the circumference of the channel, thereby minimizing the effect of flux peaking on the coolant temperature rise. Due to the clearances required between elements with the close-packed arrangement, it is only possible to approach a close-packed lattice. Therefore, some flux peaking can be expected with this lattice configuration.

Because it is difficult to redistribute fuel plates within a fuel element, the uneven burnup of fuel results in poor utilization of fuel. For the square element in the spaced lattice, the consequent increase in fuel cycle costs is quite noticeable.

\section{3) Flow Rate and Pumping Power}

Low flow rates result in lower equipment and operating costs in the external system, viz. heat exchangers, piping, pumps, and purification system. Low pumping power also increases the efficiency of the plant. The pumping power and flow rate are higher for the spaced square element than for the close-packed square and circular elements.

4) Growth of Fuel Due to Burnup

This is a problem for any element, but is more serious for the circular element. Growth of the fuel causes a change in the coolant channel geometry. For the square plate-type element, the reduction in coolant channel thickness by swelling that accompanies burnup is small. However, the fuel cylinders of the 
circular element grow in proportion to both their diameter and thickness, producing significant changes in the thickness of coolant channels. This effect can be largely overcome by proper design of the fuel cylinder spacing.

5) Enrichment

It is advantageous to operate a reactor with as low an enrichment as possible. Even though less uranium is required for a close-packed core of the Piqua size, the higher enrichment and faster burnup of fuel results in higher fuel cycle costs for the square element than for the circular type.

Table II summarizes the advantages and disadvantages of the two fuel element types.

\section{TABLE II}

RELATIVE MERITS OF THE FUEL ELEMENT T YPES

\begin{tabular}{|c|c|c|}
\hline Fuel Element Type & Advantages & Disadvantages \\
\hline Square (spaced lattice) & $\begin{array}{l}\text { 1. Low enrichment } \\
\text { 2. Upper grid plate } \\
\text { can readily be } \\
\text { used }\end{array}$ & $\begin{array}{l}\text { 1. High flux peaking in the } \\
\text { element } \\
\text { 2. High flow rate }\end{array}$ \\
\hline $\begin{array}{l}\text { Square (close-packed } \\
\text { lattice) }\end{array}$ & $\begin{array}{l}\text { 1. Low flux peaking } \\
\text { in the element } \\
\text { 2. Smaller core } \\
\text { 3. Moderate flow rate }\end{array}$ & $\begin{array}{l}\text { 1. Difficult to use upper grid } \\
\text { plate } \\
\text { 2. High enrichment }\end{array}$ \\
\hline Circular & $\begin{array}{l}\text { 1. Low enrichment } \\
\text { 2. Upper grid plate can } \\
\text { readily be used } \\
\text { 3. Low flux peaking in } \\
\text { the element } \\
\text { 4. Low flow rates }\end{array}$ & $\begin{array}{l}\text { 1. Fuel cylinder growth due to } \\
\text { burnup }\end{array}$ \\
\hline
\end{tabular}




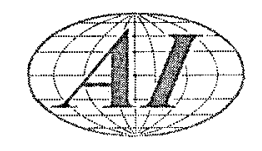

\section{SELECTION OF THE FUEL ELEMENT FOR THE PIQUA REACTOR}

The spaced-lattice square element was eliminated because of the poor thermal performance associated with the large element flux peaking. The close-packed square element and the circular element are seen to have approximately equal thermal performance. From a nuclear standpoint, however, the close-packed square element requires an enrichment more than fifty percent higher than that of the circular element when used in a core of the Piqua size. Because a top grid plate cannot easily be used with a close-packed core, a more complex mechanical design is required for the square element. The only disadvantage associated with the circular element is the fuel growth due to burnup, and this can be overcome by proper design of the fuel cylinder clearances.

Therefore, because of fewer associated mechanical problems and the considerably lower required enrichment, the circular element was selected over the close-packed square element for the Piqua reactor. 


\section{METHOD OF ANALYSIS}

\section{A. GEOMETRY}

The analysis of the Piqua core was based on the circular element shown in Figure 2, which is designed for equal power density in both fuel cylinders. This equivalence was accomplished by equating the fuel-to-moderator ratio of the inner and outer cylinders. From the fin geometry, cladding thickness, and fuel fraction, five relationships were obtained which reduced to a cubic in $p$, the cylinder thickness:

$$
F p^{3}-B p^{2}+E=0
$$

where

$$
\begin{aligned}
& F=2 s-2 y-0.12, \\
& B=3 a\left(\frac{s^{2} \sqrt{3}}{2 \pi}\right) \\
& E=\frac{a^{3}}{64}\left(\frac{s^{2} \sqrt{3}}{2}\right)^{2}
\end{aligned}
$$

The cell geometry can then be obtained from the following equations:

$$
\begin{aligned}
& D_{1}=\frac{a^{3}}{16}\left(\frac{s^{2} \sqrt{3}}{2 \pi}\right) \frac{1}{p^{3}} \\
& D_{3}=\left(\frac{s^{2} \sqrt{3}}{2 \pi}\right) \frac{a}{p}-D_{1} \\
& D_{2}=\frac{D_{3}+D_{1}}{2}
\end{aligned}
$$

* A table of nomenclature is given on page 29. 


$$
l=\frac{D_{3}-D_{1}-2 p-0.14}{4}
$$

In the above equation's, a cladding thickness of 0.035 inch and a containe $r$ can thickness of 0.030 inch were assumed.

\section{B. POWER CAPACITY IN THE HOTTEST FUEL ELEMENT}

The heat transfer analysis was based on a single cell. The control rods were assumed to be operated in a way such that the axial heat generation rate in the reactor will follow the equation

$$
q=q_{0} \cos \frac{\pi x}{L_{0}}
$$

Of this $q$, a fraction $b$ is generated in the organic moderator and coolant. An additional factor was included to take into account a skewed axial distribution of the flux due to control rods.

The thermal capacity of the core is limited by the surface temperature of the cladding. Using the above heat generation distribution, the heat transfer capability of the fuel element can be obtained from the expression

$$
\begin{aligned}
& 2 L_{0} h A\left(t_{s m}-T_{0}\right) \sin \left(\frac{\pi L}{2 L_{0}}\right)
\end{aligned}
$$

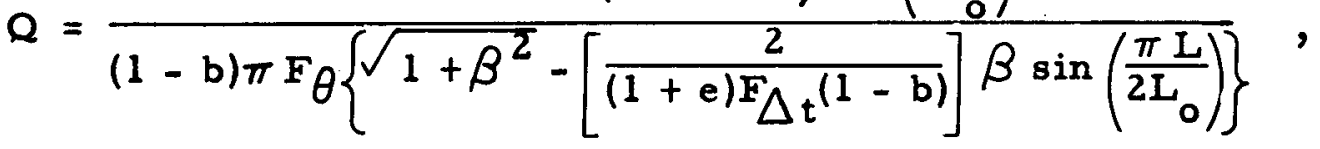

where $\beta$ is defined as

$$
\beta=\frac{(1-b+a) F_{\Delta t}{ }^{h A L_{o}}}{(1-b) F_{\theta} W C_{p} \pi}
$$




\section{HEAT TRANSFER COEFFICIENT}

The heat transfer coefficient was determined from the relation

$$
\frac{\mathrm{hD}_{\mathrm{e}}}{\mathrm{k}}=0.015\left(\frac{\mathrm{D}_{\mathrm{e}} \rho \mathrm{V}}{\mu}\right)^{0.85}\left(\frac{\mathrm{C}_{\mathrm{p}} \mu}{\mathrm{k}}\right)^{0.15}
$$

This equation is the result of experiments on various polyphenyls performed at Atomics International. ${ }^{2}$ The correlation of these data is shown in Figure 5.

Experimental data obtained at the OMRE ${ }^{*}$ indicate that the heat transfer coefficient does not change significantly with polymer content up to a composition of about 30 percent polymer. Therefore, no decrease in this coefficient was assumed with polymer buildup.

D. EFFECTIVE HEAT TRANSFER AREA

From the fin configuration shown in Figure 2, the effective heat transfer area per unit length of element can be obtained from the expression

$$
A=A_{0}+\Omega A_{f}
$$

where $\Omega$ is the fin efficiency as found in Figure 16.13-C, curve B, of Reference 3 .

E. CORE PRESSURE DROP

The pressure drop through the element was calculated from the equation

$$
\Delta P=\frac{2 f^{\prime} \rho V^{2} L}{g_{c} D_{e}}
$$

* Organic Moderated Reactor Experiment, operated by Atomics International for the AEC in Arco, Idaho. 
is

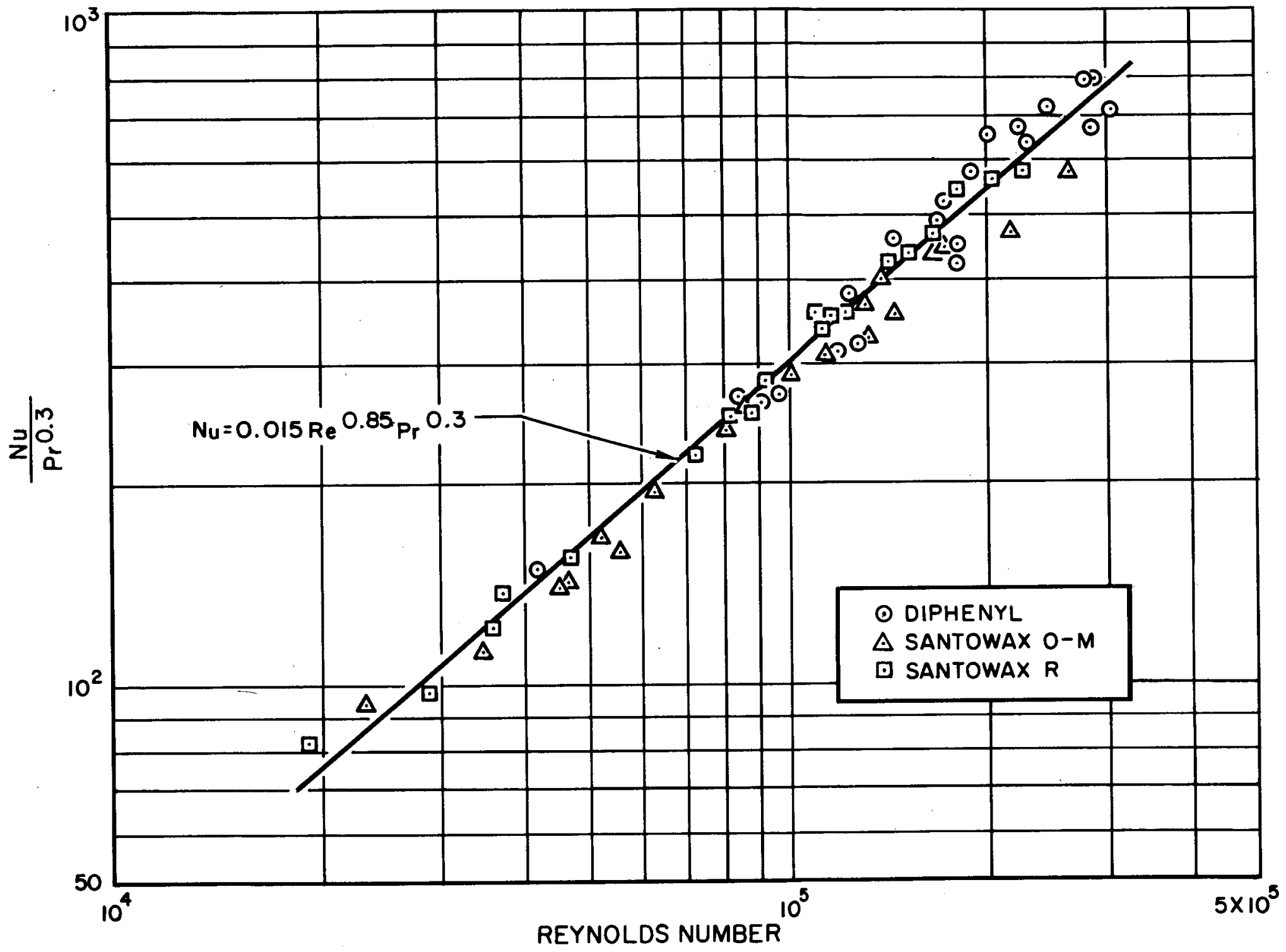

Figure 5. Heat Transfer Coefficient Correlation 


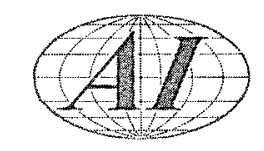

where $f^{\prime}$ was determined experimentally for longitudinal fins of this type. Entrance and exit effects were estimated to be 1.5 velocity heads.

\section{F. BURNOUT HEAT FLUX}

The burnout heat flux for the reactor was calculated by means of the Griffith correlation. Figure 6 shows this correlation; along with experimental burnout data for polyphenyls. The curves on this figure are \pm 33 percent deviations from the mean and were found to include most of the available burnout data. For the Piqua OMR pressure condition, i.e., a reduced pressure of about 0.15 , the experimental data are seen to be higher than the predicted burnout values. To be conservative, the lower limit of this curve was used to estimate the burnout heat flux.

\section{G. TOTAL REACTOR POWER}

Equation 10 is based on a maximum surface temperature limitation and the mixed-mean outlet temperature. Assuming that all the elements have the same axial flux distribution, the total thermal capacity of the reactor becomes

$$
P=\frac{N Q}{\left(\frac{\phi_{p}}{\phi_{a}}\right)_{r}}
$$

\section{H. TOTAL COOLANT FLOW RATE}

If the reactor is orificed to give equal temperature rise in each element, the total flow rate becomes

$$
w_{t}=\frac{N W(1+e)}{\left(\frac{\phi_{p}}{\phi_{a}}\right)_{r}}
$$

If the reactor is orificed for equal maximum surface temperature in all the elements, this flow rate can be reduced by about 5 percent. 

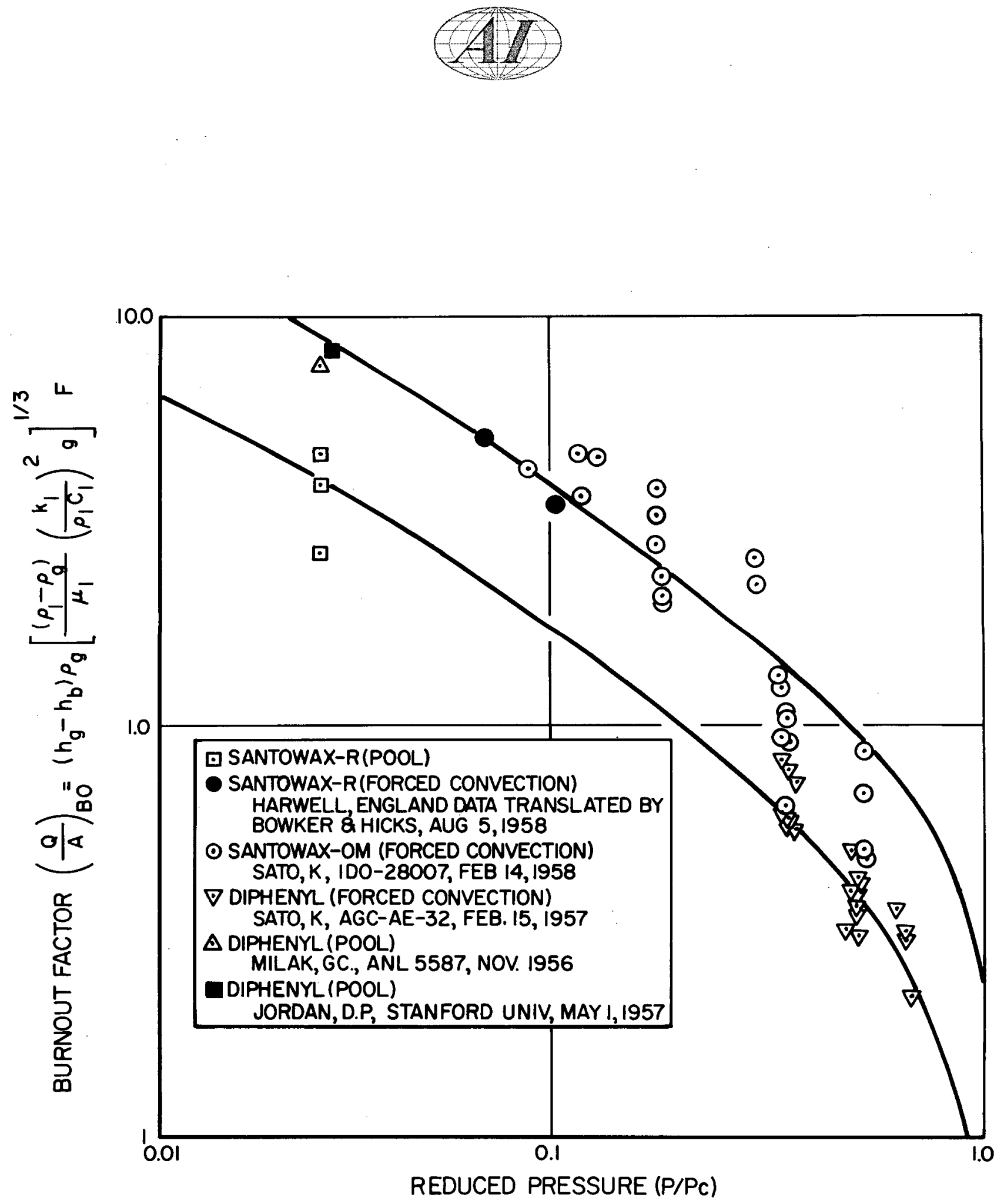

Figure 6. Burnout Correlation 
Pyrolytic and radiolytic damage to the coolant cause the formation of higher polymers. These polymers are removed by a purification system which is operated to maintain the polymer content at 30 percent. Therefore, all calculations were based on this composition. The properties of the circular fuel element are listed in Table III, and the physical properties of the organic coolant are shown in Table IV. ${ }^{5}$

\section{TABLE III}

PROPERTIES OF THE CIRCULAR FUEL ELEMENT

Coolant Flow Area (sq. in.)

Hot and unswelled

Hot and swelled

Average Equivalent Diameter (in.)

0.104

Cell Composition (vol \%)

Fuel

17.8

Moderator

67.4

Aluminum

12.3

Stainles s Steel

2.5

Fue1-to-Moderator Ratio

0.264

TABLE IV

PHYSICAL PROPERTIES OF THE ORGANIC COOLANT

\begin{tabular}{lc}
\hline \hline Organic Coolant: $0-, \mathrm{m}-$, p-terphenyl isomers \\
Composition (wt \%) \\
o-terphenyl & 11.7 \\
m-terphenyl & 60.0 \\
p-terphenyl & 28.0 \\
diphenyl & 0.3 \\
Physical Properties (570 $\mathrm{F}, 30 \%$ high boilers) \\
Specific heat & $0.50 \mathrm{Btu} / \mathrm{lb}-{ }^{\circ} \mathrm{F}$ \\
Viscosity & $0.80 \mathrm{centipoise}$ \\
Thermal conductivity & $0.067 \mathrm{Btu} / \mathrm{hr}-\mathrm{ft}-{ }^{\circ} \mathrm{F}$ \\
Density & $57.5 \mathrm{lb} / \mathrm{ft}^{3}$ \\
\hline
\end{tabular}




\section{RESULTS}

The generalized analysis indicates that the circular element with the smallest practical diameter will give the best thermal performance. The smallest hexagonal cell which can be used with the proposed control rod drive is 6 inches across the flats. The reactor core is 4-1/2 feet high and contains 85 cell positions, as shown in Figure 7. Seven control rods are required; these can be located either in separate cells or inside the fuel elements. The control rods will be operated in direct contact with the organic. If a control rod is operated in a separate cell position, flux peaking occurs in the elements adjacent to the control rod cell when the poison rod is removed. This flux peaking is eliminated if the poison rod operates within an element.

\section{A. CORE FLUX PEAK-TO-AVERAGE}

Results of one- and-two-dimensional source calculations for the core, based on various control rod positions, are summarized in Table $V$ for the most severe case.

\section{TABLE V}

FLUX PEAKING FACTORS IN THE REACTOR CORE

\begin{tabular}{l|c|c}
\hline \hline & $\begin{array}{c}\text { Separate Control } \\
\text { Cells }\end{array}$ & $\begin{array}{c}\text { Control Rods } \\
\text { Inside Fuel } \\
\text { Elements }\end{array}$ \\
\hline $\begin{array}{l}\text { Axial Peak-to-Average } \\
\text { Radial Peak-to-Average }\end{array}$ & 1.44 & 1.44 \\
Element Peak-to-Average & 1.75 & 1.50 \\
1. Adjacent to empty control cell & & 1.05 \\
2. Normal element & 1.42 & 1.05 \\
\hline
\end{tabular}




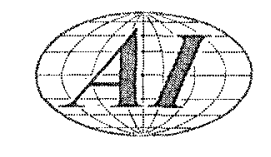

B. HOT CHANNEL FACTORS

The fuel element geometry calculated by the method mentioned previously was modified slightly to incorporate the clearances necessary for manufacturing tolerances, fabrication tolerances, thermal expansion, and growth due to burnup. The manufacturing and fabrication tolerances assumed for the hot channel factor estimates are listed in Table VI. Thermal expansion was based on the operating temperatures of the fuel element components. The average fuel burnup will be $3000 \mathrm{Mwd} / \mathrm{T}$. Swelling for this amount of burnup was estimated from available experimental data to be 2 volume percent.

TABLE VI

MANUFACTURING TOLERANCES FOR THE CIRCULAR ELEMENT

\begin{tabular}{|c|c|}
\hline Component & $\begin{array}{l}\text { Tolerance } \\
\text { (in.) }\end{array}$ \\
\hline $\begin{array}{l}\text { 1. Fuel Casting } \\
\text { ID } \\
\text { OD (machined) } \\
\text { Thickness }\end{array}$ & $\begin{array}{l} \pm 0.003 \\
\pm 0.003 \\
\pm 0.007\end{array}$ \\
\hline $\begin{array}{l}\text { 2. Finned Cladding as Extruded } \\
\text { Fin height } \\
\text { Fin tip to bottom of cladding }\end{array}$ & $\begin{array}{l} \pm 0.002 \\
\pm 0.005\end{array}$ \\
\hline $\begin{array}{l}\text { 3. Finned Fuel Cylinder } \\
\text { ID } \\
\text { OD } \\
\text { Thickness }\end{array}$ & $\begin{array}{l} \pm 0.013 \\
\pm 0.013 \\
\pm 0.017\end{array}$ \\
\hline $\begin{array}{l}\text { 4. Stainless Steel Container Cans, as Drawn } \\
\text { Inner Can } \\
\text { Outer radius from imaginary center line } \\
\text { Thickness } \\
\text { Outer Can } \\
\text { Inner radius from imaginary center line } \\
\text { Thickness }\end{array}$ & $\begin{array}{l} \pm 0.003 \\
\pm 0.003 \\
\pm 0.003 \\
\pm 0.003\end{array}$ \\
\hline 5. Location of Container Cans (eccentricity) & \pm 0.002 \\
\hline
\end{tabular}


Based on these tolerances, hot channel factors were calculated for both the hot and swelled and the hot and unswelled cases. The flow distribution within the channels of the element was found to be more undesirable for the hot and swelled case. These hot channel factors are listed in Table VII for the worst case (i.e., with separate control cells). With control rods inside fuel elements, the element source peaking is much less, as was shown in Table V. The hot channel factors for the two different cases then become as listed below:

1. Separate Control Cells

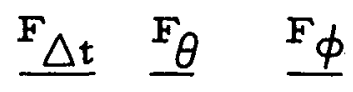

Elements adjacent to empty control cell

$\begin{array}{lll}2.05 & 2.47 & 1.79\end{array}$

Normally located elements

$\begin{array}{lll}1.74 & 1.83 & 1.32\end{array}$

2. Control Rods Inside Elements

$\begin{array}{lll}1.74 & 1.83 & 1.32\end{array}$

TABLE VII

HOT CHANNEL FACTORS

\begin{tabular}{|c|c|c|c|}
\hline Hot Channel Factor & $\mathrm{F}_{\Delta \mathrm{T}}$ & $\mathbf{F}_{\theta}$ & $F_{\phi}$ \\
\hline 1. Distortion of axial power distribution & 1.00 & 1.06 & 1.06 \\
\hline 2. Inability to predict flux & 1.10 & 1.10 & 1.10 \\
\hline 3. Improper orificing ${ }^{(1)}$ & 1.05 & 1.04 & 1.00 \\
\hline $\begin{array}{l}\text { 4. Local heat transfer coefficient } \\
\text { variation }\end{array}$ & 1.00 & 1.15 & 1.00 \\
\hline $\begin{array}{l}\text { 5. Accuracy of heat transfer coefficient } \\
\text { correlation }\end{array}$ & 1.00 & 1.10 & 1.00 \\
\hline 6. Spacers between subsections ${ }^{(2)}$ & 1.00 & 1.00 & 1.05 \\
\hline 7. Variation in fuel thickness & 1.03 & 1.03 & 1.03 \\
\hline 8. Mechanical channel tolerances & 1.46 & 1.10 & 1.00 \\
\hline \multirow[t]{2}{*}{ 9. Element source peak-to-average ${ }^{(3)}$} & 1.18 & 1.42 & 1.42 \\
\hline & $\overline{2.05}$ & $\overline{2.47}$ & $\overline{1.79}$ \\
\hline
\end{tabular}

(1) The orifices will be adjusted from fuel element outlet temperatures and therefore will include effects such as flow distribution in the plenum chambers.

(2) This effect, which is caused by the aluminum spacers between fuel cylinder subsections, is a local effect. By extension of the fins in this region, the effect of $F_{\Delta T}$ and $F_{\theta}$ can be made negligible.

(3) The source peak-to-average is 1.05 for a normally located element and 1.42 in an element adjacent to an empty control cell. Because of the spiralled coolant channel, the worst flux peaking only increases the temperature rise by a factor of 1.18 . 


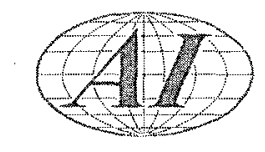

\section{REACTOR PERFORMANCE}

The performance of the Piqua Reactor, based on a core loading of circular elements, is outlined in Table VIII. The operating conditions were calculated for separate control cells and also for control rods placed inside of fuel elements. The thermal power was calculated using Equation 10 and the hot channel factors listed in Table VII, and was increased by 7 percent by including the following considerations:

1) Radial heat conduction (conduction from the hot spot in the hot channel to the colder channel on the opposite side of the fuel cylinder). This effect permits a 6 percent increase in power.

2) Circumferential heat conduction (conduction around the periphery of the fuel cylinder to colder regions on the perimeter). This effect permits a 1 percent increase in reactor power.

For the case with separate control cells, the maximum surface temperature limitation of $750^{\circ} \mathrm{F}$ occurs at 115 percent of the rated power. At normal rated power, the maximum surface temperature is $727^{\circ} \mathrm{F}$. By placing the control rods inside of the fuel elements, the overload margin can be increased from 15 to 61 percent. The maximum surface temperature at rated power for this case is less than $700^{\circ} \mathrm{F}$. From Table VIII, it can be seen that boiling burnout is not a problem, even for the higher power levels.

For $45.5 \mathrm{Mw}$ operation, the maximum fuel temperature for the circular element is below $850^{\circ} \mathrm{F}$. It is believed that this low temperature will allow a long burnup lifetime. In the study of the circular element, it was realized that the two concentric cylinders could be combined into a thicker single cylinder with longer fins. The principle advantages of a single fuel cylinder are the savings in fabrication cost and the greater ease of handling and inspection. The penalty paid for these advantages is a reduction in heat transfer capability and an increase in fuel alloy temperatures. It is estimated that with the present flow rates and the surface temperature limitation, the power capability of the Piqua core would be cut 20 percent if the single-cylinder fuel element were used. 


\section{TABLE VIII}

PIQUA OPERATING CONDITIONS WITH THE CIRCULAR ELEMENT

\begin{tabular}{|c|c|c|c|c|}
\hline \multirow{3}{*}{$\begin{array}{l}\text { Thermal power, } \mathrm{Mw} \\
\text { Total flow rate, } \mathrm{lb} / \mathrm{hr}\end{array}$} & \multicolumn{2}{|c|}{$\begin{array}{l}\text { Separate } \\
\text { Control Cells }\end{array}$} & \multicolumn{2}{|c|}{$\begin{array}{l}\text { Control Rods } \\
\text { Inside Elements }\end{array}$} \\
\hline & 45.5 & 55.5 & 45.4 & 75 \\
\hline & $5.5 \times 10^{6}$ & $5.5 \times 10^{6}$ & $5.5 \times 10^{6}$ & $5.5 \times 10^{6}$ \\
\hline Maximum surface temperature, $\quad F$ & 727 & 750 & 682 & 750 \\
\hline Maximum fuel temperature, $\bullet F$ & 832 & 871 & 749 & 857 \\
\hline Core inlet temperature, ${ }^{\circ} \mathrm{F}$ & 518 & 509 & 518 & 482 \\
\hline Core mixed-mean outlet temperature, ${ }^{\circ} F$ & 575 & 575 & 575 & 575 \\
\hline $\begin{array}{l}\text { Maximum outlet temperature from hot } \\
\text { channel, }{ }^{\circ} \mathrm{F}\end{array}$ & 635 & 644 & 617 & 643 \\
\hline Maximum heat flux, Btu/hr-ft ${ }^{2}$ & 132,000 & 161,000 & 94,000 & 155,000 \\
\hline Burnout heat flux, Btu/hr-ft ${ }^{2}$ & 560,000 & 560,000 & 550,000 & 550,000 \\
\hline Maximum coolant velocity, ft/sec & 19.4 & 19.4 & 15.3 & 15.3 \\
\hline Core pressure drop, psi & 40 & 40 & 26 & 26 \\
\hline Core pumping power (theoretical), kw & 209 & 209 & 136 & 136 \\
\hline Total surface area, $\mathrm{ft}^{2}$ & 4320 & 4320 & 4710 & 4710 \\
\hline Effective surface area, $\mathrm{ft}^{2}$ & 3930 & 3930 & 4320 & 4320 \\
\hline Uranium loading, $\mathrm{kg}$ & 6790 & 6790 & 7400 & 7400 \\
\hline Number of fuel elements & 78 & 78 & 85 & 85 \\
\hline
\end{tabular}




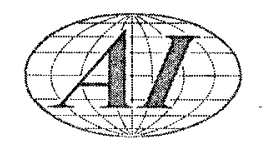

As stated previously, the maximum fuel temperature was too low to be considered as a design parameter for the square and double-cylinder elements. However; this is not completely true in the case of a single-cylinder element. Due to the increased thickness of the cylindrical fuel and the higher heat flux associated with the single-cylinder element, the maximum fuel temperature is much higher. Since it is possible that these higher temperatures may increase the growth due to fuel burnup, development of the single-cylinder elements has been postponed as of the date of this report. 
IX. SUMMARY

This investigation compares the relative merits of the square (parallel flat plate) with the circular (concentric cylindrical shell) type fuel elements for the Piqua Organic Moderated Reactor.

The square element can be arranged in either a spaced or closed-packed lattice, as shown in Figure 3. The closed-packed lattice allows uniform heat generation in each plate of the element but requires a high coolant flow rate because of the large coolant flow area. The spaced lattice design reduces the coolant flow area but causes flux peaking in the element. This is due to thermalization of a large fraction of the neutrons by the organic fluid in the spaces between the elements.

The basic advantage of the circular element is that although it permits the use of a small coolant flow area, it does not exhibit the high flux peaking in the fuel caused by the large volume of moderator between the elements. As seen in Figure 3, in addition to providing ample moderator between the fuel elements, the circular element also provides for a sizable volume of moderator inside the fuel cylinders. This balance of external and internal moderator practically eliminates flux peaking in the element. Another advantage is that only a small fraction of the total moderator cross-sectional area is used for coolant flow, and therefore a low total flow rate is sufficient to give the high velocities required for cooling.

Tables I and II list the various advantages and disadvantages of these elements. From Table $I$, it can be seen that because of pronounced flux peaking within the element, the spaced square element is least desirable from a thermal standpoint. The close-packed square element and the circular type element are seen to possess approximately the same thermal capability.

The close-packed square element, however, requires a much higher fuel enrichment because the core is smaller and the resonance escape is lower. Due to the lower enrichment required and because of the smaller number of associated mechanical problems, the circular element was selected as the most promising for the Piqua reactor. 


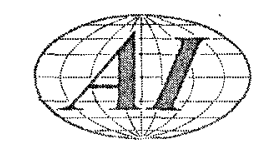

There are two different methods of utilizing control rods in a core fueled with circular elements. The first method, which was used to compare the circular to the square element, employs control rods in separate lattice positions. Since the control rods operate in direct contact with the organic, the entire control cell will be filled with moderator when the rod is withdrawn. This produces a large flux peak in the neighborhood of the control cell. To overcome this peaking, a second method was investigated in which the control rods are operated within the inner container can of the fuel element.

Operating conditions for the Piqua reactor, based on the circular element, are listed in Table VIII. A maximum allowable cladding surface temperature of $750^{\circ} \mathrm{F}$ was set as a design limitation for the reactor. At a reactor operating power of $45.5 \mathrm{Mwt}$, with the control rods operating in separate cell positions, this surface temperature limitation would be reached at 115 percent power. Under normal operating conditions the maximum surface temperature would be $727^{\circ} \mathrm{F}$. By placing the control rods inside the fuel elements, the surface temperature limitation would be reached at 161 percent of rated power, allowing an increased capacity of 40 percent over the former case. Under normal operating conditions the maximum surface temperature would be reduced to less than $700^{\circ} \mathrm{F}$. Because the maximum fuel temperature for the circular element is well below limiting values for both arrangements of control rods, maximum fuel temperature was not considered to be an important design parameter. 


\section{REFERENCES}

1. E. B. Baumeister and C. W. Wheelock, NAA-SR-1998, November 15, 1957

2. M. Silberberg and D. A. Huber, NAA-SR-2796, January 15, 1959

3. D. Q. Kern, Process Heat Transfer (New York: McGraw-Hill Book Co., 1950), p. 543

4. P. Griffith, 57-HT-21, ASME-AIChE Heat Transfer Conference, August 11, 1957

5. R. H. Gercke, F. C. Silvey, and G. Asanovich (unpublished memorandum No. 3223, Atomics International, Canoga Park, Calif.) 
$A=$ Effective heat transfer area per unit length, $\mathrm{ft}^{2} / \mathrm{ft}$

$A_{f}=$ Fin area per unit length, $\mathrm{ft}^{2} / \mathrm{ft}$

$A_{0}=$ Area between fins per unit length, $\mathrm{ft}^{2} / \mathrm{ft}$

$a=$ Fraction of the core power generated in the organic coolant

$B=$ Constant

$\mathrm{b}=$ Fraction of the core power generated in the coolant and moderator $\mathrm{C}_{\mathrm{p}}=$ Specific heat of organic, $\mathrm{Btu} / \mathrm{lb}-{ }^{\circ} \mathrm{F}$

$\mathrm{D}_{1}=$ Mean diameter of inner fuel cylinder, $\mathrm{ft}$

$D_{2}=$ Average of $D_{1}$ and $D_{2}$, ft

$D_{3}=$ Mean diameter of outer fuel cylinder, $f t$

$\mathrm{D}_{e}=$ Equivalent diameter of channel, $\mathrm{ft}$

\section{$E=$ Constant}

$e=$ Leakage fraction

$f^{\prime}=$ Friction factor

$F_{\Delta t}=$ Temperature rise hot channel factor

$F_{\theta}=$ Film drop hot channel factor

$F=$ Constant

$\mathrm{g}_{\mathrm{c}}=$ Conversion factor

$\mathrm{h}=$ Heat transfer coefficient, Btu $/ \mathrm{hr}-\mathrm{ft}^{2}-{ }^{\circ} \mathrm{F}$

$\mathrm{k}=$ Thermal conductivity of organic, Btu/hr-ft- ${ }^{\circ} \mathrm{F}$

$\ell=$ Fin height, $\mathrm{ft}$

$\mathrm{L}=$ Active length of fuel element, $\mathrm{ft}$

$L_{o}=$ Active length of fuel element plus reflector savings, ft
$N=$ Number of fuel elements

$\mathrm{p}=$ Thickness of fuel cylinders, $\mathrm{ft}$

$P=$ Reactor thermal power

$\mathrm{q}=$ Heat generation rate per unit length, Btu/hr-ft

$q_{o}=$ Maximum heat generation per unit length, Btu/hr-ft

$Q=$ Total heat generation for maximum element, Btu/hr

$\mathrm{S}=$ Distance between flats of hexagonal cell, $\mathrm{ft}$

$\mathrm{t}_{\text {sm }}=$ Maximum surface temperature, ${ }^{\circ} \boldsymbol{F}$

$\mathrm{T}_{\mathrm{o}}=$ Mixed-mean outlet temperature, ${ }^{\circ} F$

$\mathrm{V}=$ Maximum coolant velocity, $\mathrm{ft} / \mathrm{sec}$

$\mathrm{w}=$ Flow rate per element, $\mathrm{lb} / \mathrm{hr}$

$\mathrm{W}_{\mathrm{T}}=$ Total flow rate for reactor, $\mathrm{lb} / \mathrm{hr}$

$\mathrm{X}=$ Axial distance from center of element, $\mathrm{ft}$

$\mathrm{y}=$ Minimum distance between cylindrical elements, $\mathrm{ft}$

$a=$ Cross sectional area of cell, $\mathrm{ft}^{2}$

$\beta=\frac{(1-b+a)}{(1-b)} \frac{F_{\triangle T}}{F_{\theta}} \frac{h_{A L}}{\mathrm{WC}_{\mathrm{p}}}$

$\mu=$ Viscosity of organic, $\mathrm{lb} / \mathrm{ft}$-sec

$\rho=$ Density of organic, $\mathrm{lb} / \mathrm{ft}^{3}$

$\left(\frac{\phi_{\mathrm{p}}}{\phi_{\mathrm{a}}}\right)$

$\Omega=$ Fin efficiency 